\title{
Simulating the Ideal Body Mass in Adult Human Samples
}

\author{
Md. Abdul Hakim \\ Discipline of Mathematics and Science, Zia Hasan International School, Karatia, Tangail, Bangladesh
}

Email address:

info.hakim.bd@gmail.com

To cite this article:

Md. Abdul Hakim. Simulating the Ideal Body Mass in Adult Human Samples. International Journal of Sports Science and Physical Education. Vol. 2, No. 4, 2017, pp. 57-60. doi: 10.11648/j.jisspe.20170204.12

Received: October 8, 2017; Accepted: October 19, 2017; Published: November 15, 2017

\begin{abstract}
Estimating ideal body mass in adult human samples in a specific geographic level is vital for effective health promotion programmes in order to seeking better health services. Lack of nutritional knowledge and information gap on various health and nutritional tools affect the ability of national and international agencies to manage serious health related risks in the community. A solution to this challenge would be to develop a method that simulates reliable statistics on assessing the ideal body mass in adult human samples. This paper provides a significant appraisal of the biophysical methodologies for estimating ideal body mass to mitigate health problems of samples at different sites. There is no procedure in this ground that can be used to assume the ideal body mass in human samples in health physics and nutritional mathematics. The physical educators are often in confusion to direct the advice of taking proper exercise which would be benificial for the learners' health. The aim of this study is making a dot over these ongoing hesitations simulating a biophysical modeling in nutrition counseling to sustain long term sound health. The study findings is the mathematical equation (4) that can be a superb modeling as an instructive tool in physical education.
\end{abstract}

Keywords: Physical Education, Ideal Body Mass, Nutritional Mathematics, Malnutrition, Biostatistics and Nutritional Simulation, Human Samples

\section{Introduction}

About 2 billion people in the world suffer from various degrees of malnutrition [1-3]. Malnutrition is an underlying cause of deaths of about 2.6 million children each year-a third of child deaths globally [4-6]. There are 73.9\%, 63.3\% and $57.9 \%$ overweight populations in North America, Oceania and Caribbean regions respectively [7-9].

One in every four of the world's children is stunted and in developing countries this is as high as one in three [10-12]. Undernutrition accounts for $11 \%$ of the global burden of diseases and is considered the supreme risk to health status [13-15].

Childhood malnutrition leads to stunted growth and inflamed mortality and morbidity which are lowering the survival opportunities of adults in their later life span [16-19]. About 4 of every 5 malnourished children live in South-EastAsia region accounting some $83 \%$ of their deaths to be liable to mild to moderate malnutrition intensity [20, 21]. These health giants are eating up the world's population day by day and so health problems are in need of identification to overcome these sorry tales with a view to meet healthy samples of population in different communities [22-24]. Therefore, this study is done to formulate a simple biophysical simulating of ideal body mass to sustaing healthy health status taking different health-suitable physical exercise.

\section{Methodology}

This is a methodological review study to form a biophysical model for simulating ideal body mass in adult human samples. A wide range of instruments have been collected from the logarithmic biophysical modulator in nutritional physics, unit bracket method in biological mathematics, definitions and equations on weight and mass in biophysics. These instruments have then undergone on different mathematical music to simulate a new formula in computational physics for estimating ideal body mass in human samples in a population aiming to continue healthy health status in human population in health statistics. 


\section{Results}

Let's move with the logarithmic biophysical modulator [25, $26]$ to estimate the ideal body mass in $\mathrm{kg}$ in adult human samples where $\mathrm{m}_{\mathrm{kg}}$ is considered as body mass in $\mathrm{kg}, \mathrm{h}_{\mathrm{cm}}$ as body height in $\mathrm{cm}$ and $\mathrm{H}$ as modulator of health status,

$$
\mathrm{H}=\log ^{-1}\left(4+\log _{\mathrm{kg}}-2 \log \mathrm{h}_{\mathrm{cm}}\right)
$$

We can get the ideal body mass using the value of $\mathrm{H}$ as 18 to 25 in equation (1) as per the WHO's BMI classification [27]. So, we get the following equation where $m_{i}$ is considered as the ideal body mass in $\mathrm{kg}$ in adult human samples in a population,

$$
1 / 8 \int_{18}{ }^{25} \mathrm{H} \mathrm{dH}=\log ^{-1}\left(4+\operatorname{logm}_{\mathrm{i}}-2 \operatorname{logh} \mathrm{cm}_{\mathrm{cm}}\right)
$$

We get the following equation solving the integration [28$32]$ in equation (2),

$$
\begin{aligned}
& 1 / 8\left[\mathrm{H}^{2} / 2\right]_{18}^{25}=\log ^{-1}\left(4+\operatorname{logm}_{\mathrm{i}}-2 \operatorname{logh}_{\mathrm{cm}}\right) \\
& \text { Or, } 1 / 8\left[25^{2} / 2-18^{2} / 2\right]=\log ^{-1}\left(4+\operatorname{logm}_{\mathrm{i}}-2 \operatorname{logh}_{\mathrm{cm}}\right) \\
& \text { Or, } 1 / 8 \times 150.5=\log ^{-1}\left(4+\operatorname{logm}_{\mathrm{i}}-2 \operatorname{logh}_{\mathrm{cm}}\right) \\
& \text { Or, } 18.8125=\log ^{-1}\left(4+\operatorname{logm}_{\mathrm{i}}-2 \operatorname{logh}_{\mathrm{cm}}\right)
\end{aligned}
$$

Taking $\log$ [29] in both side of equation (3),

$$
\log 18.8125=4+\operatorname{logm}_{\mathrm{i}}-2 \operatorname{logh} \mathrm{h}_{\mathrm{cm}}
$$

Or, $1.27=4+\operatorname{logm}_{\mathrm{i}}-2 \log \mathrm{h}_{\mathrm{cm}}$

Or, $\operatorname{logm}_{\mathrm{i}}=2 \operatorname{logh}_{\mathrm{cm}}-4+1.27$

Or, $\operatorname{logm}_{\mathrm{i}}=2 \operatorname{logh} \mathrm{cm}_{\mathrm{m}}-2.73$

$$
\text { Or, } \mathrm{m}_{\mathrm{i}}=\log ^{-1}\left(2 \operatorname{logh}_{\mathrm{cm}}-2.73\right)
$$

\section{Discussion}

Simulation reproduce the behaviour of a system using a mathematical model. Simulations have become a useful tool for the mathematical modeling of many natural systems in physics, astrophysics, climatology, chemistry and biology, human systems in economics, psychology, social science and engineering. It can be used to explore and gain new insights into the new technology and to estimate the performance of systems too complex for analytical solutions [33-41]. This study aims to introduce a newly formed simulation modeling in the branch of nutritional mathematics in estimating ideal body mass in human samples in different populations [42-50] for sustaining healthy population status in different countries. The study results can take a new turn in simulating ideal body mass in human samples evading all the previous faulty procedures. This biophysical simulation can be a spatial health microsimulation modeling constructive to design effective policies and see the governments and NGOs, environmental and spatial effects across different countries to bear up against the health and nutritional perils to make sure for ending malnutrition by 2020 [51-56].

\section{Conclusions}

Malnutrition is one of the common public health threat in the developing countries. The current study outcome is the biophysical equation (4) that can simulate ideal body mass in biological mathematics. The national and international think tank should popularize this health and nutritional simulation to reduce malnutrition intensity. Future research should adopt this cozy biophysical simulation modeling in physical education. This simulation modeling should also be explored in further study for policy designing, analysis and checking spatial effects for health condition in adult human samples in the worldwide nutritional epidemiology.

\section{Conflict of Interests}

There is no cnflict of interests regarding the publication of this manuscript.

\section{Acknowledgements}

The author would like to thank the annonymous referee, the editor and the editorial assistant for their bold comments and suggestions that were used in the splashing accomplishment of this manuscript.

\section{References}

[1] Rahman A, Chowdhury S, Karim A and Ahmed S. Factors associated with nutritional status of children in Bangladesh: A multivariate analysis. Demogr India 2008;37(1):95-109.

[2] Rahman A and Hakim MA. An epidemiological study on hygiene practice and malnutrition prevalence of beggars children in Bangladesh. Int J Nutr Diet 2016;4(1):29-46.

[3] Hakim MA and Kamruzzaman M. Nutritional status of central Bangladesh street children. Am J Food Sci Nutr Res 2015;2(5):133-137.

[4] Hakim MA and Kamruzzaman M. Nutritional status of preschoolers in four selected fisher communities. Am J Life Sci 2015;3(4):332-336.

[5] Islam $\mathrm{M}$ et al. Socioeconomic profile and health status of rickshaw pullers in rural Bangladesh. Am J Food Sci Health 2016;2(4):32-38.

[6] Rahman A. Significant risk factors for childhood malnutrition: Evidence from an Asian developing country. Sci J Public Health 2016;4(1-1):16-27.

[7] Walpole SC et al. The weight of nations: an estimation of adult human biomass. BMC Public Health 2012,12(1):439.

[8] Hakim MA and Rahman A. Health and nutritional condition of street children of Dhaka city: An empirical study in Bangladesh. Sci J Public Health 2016;4(1-1)6-9.

[9] Chowdhury MR et al. Risk factors for child malnutrition in Bangladesh: A multilevel analysis of a nationwide populationbased survey. J Pediatr 2016;172:194-201.

[10] Megabiaw B and Rahman A. Prevalence and determinants of chronic malnutrition among under-5 children in Ethiopia. Int $J$ Child Health Nutr 2013;2(3):230-236. 
[11] de Onis M, Blossne M and Eorghi E. Prevalence of stunting among pre-school children 1990-2020', Growth Assessment and Surveillance Unit. Public Health Nutr 2011;14:1-7.

[12] Kamruzzaman M and Hakim MA. Socio-economic status of child beggars in Dhaka city. J Soc Sci Human 2015;1(5): 516520 .

[13] Black RE, Allen L Hand Bhutta ZA, Caulfield LE, de Onis M, Ezzati M, Mathers $\mathrm{C}$ and Rivera J. Maternal and child undernurition: global and regional exposures and health consequences. The Lancet 2008;371(9608):243-60.

[14] Hakim MA, Talukder MJ and Islam MS. Nutritional status and hygiene behavior of government primary school kids in central Bangladesh. Sci J Public Health 2015; 3(5):638-642.

[15] Kamruzzaman $M$ et al. Patterns of behavioral changes among adolescents mokers: An empirical study. Front Biomed Sci 2016;1(1):1-6.

[16] Rahman A, Chowdhury S and Hossain D. Acute malnutrition in Bangladeshi children: Levels and determinants. Asia Pac J Public Health 2009;21(1):294-302.

[17] Kamruzzaman $M$ and Hakim MA. Food and nutrition counseling in Bangladesh: a NC4HD approach in health statistics. Am J Biol Chem 2017; 5 (1): 1-5.

[18] Rahman A and Hakim MA. Malnutrition prevalence and health practices of homeless children: a cross-sectional study in Bangladesh. Sci J Public Health 2016;4(1-1):10-15.

[19] Hakim A. Vitamin A deficiency as a global public health threat: a concern in nutritional victimization. $J$ Nutr Health Food Eng 2016; 4(5):00147.

[20] United Nations International Children's Emergency Fund(UNICEF). Malnutrition in South Asia: a regional profile, UNICEF report, 1997; p.8.

[21] Hakim MA. Nutrition counseling in homelessness: a NC4HD nexus. Int J Health Econ Pol 2017;2(1):12-15

[22] Rahman A and Kuddus A. A new model to study on physical behaviour among susceptible infective removal population. Far East J Theor Stat 2014;46(2):115-135.

[23] Hakim MA and Kamruzzaman M. The dance of poverty and education for childhood nutritional victimization in Bangladesh. J Biol Env Eng 2016;1(1):6-9.

[24] Rahman A, Harding A, Tanton R and Liu S. Simulating the characteristics of populations at the small area level: New validation techniques for aspatial microsimulation mode lin Australia. Comput Stat Data Analys 2013; 57(1):149-165.

[25] Rahman A and Hakim MA. Modeling health status using the logarithmic biophysica lmodulator. J Public Health Epidemiol 2017; 9(5):145-50.

[26] Kamruzzaman M and Hakim MA. Factors associated with the suicidal Tsunami as a menta lillness: Findings from an epidemiological study. Am J Env Sust Dev 2016;1(1):1-5.

[27] World Health Organization (WHO). BMI Classification. Global Database on Body Mass Index 2006.

[28] Broach D. Integration of clinical research documentation in electronic health records. Comput Inform Nurs 2015;33(4):142-9.
[29] Pierce RC. A brief history of logarithm. Two-Year Coll Math $J$ 1977; 8(1):22-6.

[30] Galili I. Weight and gravity teachers' ambiguity and students' confusion about the concepts. Int J Sci Eeduc 1993;15(2):14962 .

[31] Banks J et al. Discrerteevent system-simulation. Prentice Hall. p.3;2001.

[32] Sokolowski JA and Banks CM. Principles o fmodeling and simulation. Hoboken NJ; Willey. p.6;2009.

[33] Rahman A and Harding A. Some health related issues in Australia and methodologies for estimating small area health related characteristics. Online Working Paper Series 2010; WP-15, NATSEM, University of Canberra. p.1-59.

[34] Rahman A and Hakim MA. Measuring modified mass energy equivalence in nutritional epidemiology: A proposal to adapt the biophysica lmodelling approach. Int J Stat Med Res 2016;5(3):219-223.

[35] Hakim MA. Modeling food energy in bioenergetics. $J$ Adv Med Pharm Sci 2017;14(4):1-7.

[36] Rahman A et al. Dietary practices, health status and hygiene observance of slum kids: A pilot study in an Asian developing country. JP J Biostat 2016; 13(2):195-208.

[37] Kamruzzaman $M$ and Hakim MA. Social, Biology and Economic Life of Children Links on Street-Begging in Bangladesh: A Cross-Cultural Multivariate Analysis. Math Letters 2017; 3 (1): 12-19.

[38] Robinson M R et al. Population genetic differentiation of height and body mass indexa crossE urope. Nature Genetics 2015; 47:1357-1362.

[39] Rahman A. Estimating small area health related characteristics of populations: a methodo logical review. Geospat Health 2017; 12(1): 3-14.

[40] Huang SM et al. The utility of modeling and simulati on in drug development and regulatory review. J Pharm Sci 2013;102:2912-2923.

[41] Brinkman SA, Gialamas A, Rahman A et al. Jurisdictional, socioeconomic and gender inequalities in child health and development: An alysis of a national census of 5 year olds in Australia. BMJ Open 2012;2(5):1-15.

[42] Rahman A. Small area estimation through spatial microsimulation models: some methodologica lissues, Paper presented at the $2^{\text {nd }}$ General Conference of the International Microsimulation Association, The National Conference Centre Ottawa, Canada, 2 009; p.1-45 (June 8 to 10$)$.

[43] Hakim MA. Mathematical modeling of energy balancing for diet plannning in nutritiona lphysics. Int $J$ Nutr Diet 2017;5(1):29-41.

[44] Poole SA, Hart CN, Jelalian E and Raynor HA. Relationship between dietary energy and dietary quality in overweight young children: a cross-sectional analysis. Pediatr Obesity 2016;11(2):128-135.

[45] Hakim MA. Malnutrition prevalence and nutrition counseling in developing countries: a case study. Int J Nurs Health Sci 2016; 3(3):19-22. 
[46] Kamruzzaman M and Hakim MA. Basic rights on the wane, human rights on brown study: a case study on thrown away children in Bangladesh. Int Env Plan Manage 2016;2(4):29-35.

[47] Hakim MA. Biophysical modeling of dietary energy in biochemical modeling. Eur J Biophys 2017; 5 (3): 57-61.

[48] Limkon KMMR, Prodhan UK, Hakim MA and Alim MA. Study on the physicochemical and antioxidant properties of nigella honey. Int J Nutr Food Sci 2015; 4 (2): 137-140.

[49] Hakim M A and Islam M S. Elementary of food science and technology (1st edition) [ISBN 984-658-612-6], 2016; p. 3537.

[50] Hakim MA. Physicochemical properties of dhania honey. Am J Food Sci Nutr Res 2015; 2 (5): 145-148.

[51] Kamruzzaman $M$ etal. Plight of youth perception on cyber crime in South Asia. Am J Information Sci Computer Eng 2016; 2(4):22-28.
[52] Hakim MA. Nutritional status and hygiene practices of primary school goers in Gateway to the North Bengal. Int $J$ Public Health Res 2015;3(5):271-275.

[53] Hakim MA. Biophysical modeling of cellular energy in human dietetics: An appraisal in nutritional physics and cel lbiology. Am J Food Sci Nut rRes 2017;4(4):125-129.

[54] Hakim MA. Simulating the ideal body weight in human populations. Int J Biochem Biophys 2017; 5 (4): 79-82.

[55] Rahman A. Risk factors for malnutrition in Bangladeshi children, paper presentation at the Showcasing Toowoomba Area Health Research conference (STAHR-06), Centrefor Rural and Remote Area Health, University of Southern Queens land, Toowoomba 2006.

[56] Macharia PM et al. Spatial accessibility to basic public health services in South Sudan. Geospat Health 2017; 12: 510. 